\title{
Honour Crimes as Gender-Based Violence in THE UK:
}

A Critical Assessment

Nootash Keyhani*

\begin{abstract}
This article focuses on gender-based violence within the family, with an emphasis on 'honour killings'. These types of crimes are associated with the concepts of 'honour' and 'shame' within patriarchal societies. Until recently, such crimes largely escaped national scrutiny, and it is argued, to some extent still do, because they are often viewed as 'traditional or cultural practices', outside the scope of accepted state intervention. This article takes a feminist perspective with the conceptual goal to reconcile the feminist approach with multiculturalism, by removing the assumption that multiculturalism is simply moral relativism. It concludes that 'crimes of honour' should be treated as a violation of human rights and not as a religious or cultural practice.
\end{abstract}

\section{A. INTRODUCTION}

This article focuses on gender-based violence within the family with an emphasis on 'honour killings'. These types of crimes are associated with the concepts of 'honour' and 'shame' within patriarchal societies. Until recently, such crimes largely escaped national scrutiny and, it is argued, to some extent still do, because they are often viewed as "traditional or cultural practices", outside the scope of accepted state intervention.

This article takes a feminist perspective with the conceptual goal to reconcile the feminist approach with multiculturalism, by removing the assumption that multiculturalism is simply moral relativism. It falls into four main sections. It will begin with an interrogation of the concept of 'honour' itself, by examining its historical and cultural connections, ${ }^{2}$ with a brief overview of its significance today. The article then examines women's role in 'honour crimes' within the wider context of domestic violence and analyses the extent to which 'honour crimes' should be interpreted as gender-based or, alternatively, as a cultural tradition. The article warns against the inherent dangers of "categorising honour-related violence as

\footnotetext{
${ }^{*}$ LL.B. (Sussex), LL.M. (UCL), Litigation, Herbert Smith Freehills LLP.

${ }^{1}$ Radhika Coomaraswamy, 'Violence Against Women and Crimes of Honour' in Lynn Welchman and Sara Hossain, 'Honour': Crimes, Paradigms and Violence Against Women (Zed Books 2005).

${ }^{2}$ Sharon K Araji, 'Crimes of Honour and Shame: Violence Against Women in NonWestern and Western Societies' (2000) The Red Feather Journal of Postmodern Criminology 22-23.
} 
primarily cultural," ${ }^{3}$ through a feminist perspective. However, it also acknowledges that to completely dismiss any cultural aspect is severely problematic and therefore calls for a more balanced approach, which takes into account the benefits and detriments of both the cultural and the genderbased arguments. ${ }^{4}$

The article later examines the ways in which male defendants in the English courts invoke culture as a defence, exploring what problems this poses for the victimised women. ${ }^{5}$ An analysis of leading legal judgments illustrates that, although the "judiciary are inclined towards viewing 'honour' as primarily cultural rather than patriarchal, in some cases they have begun to take a more gender-based or 'mature multiculturalism' approach." ${ }^{, 6}$ Despite an alarming judicial comment, ${ }^{7}$ overall, the English courts have resisted accepting the cultural argument as an acceptable defence. $^{8}$

In the final part, this article looks at the arguments of 'mature multiculturalism' put forward by feminists such as Okin. It has been argued that, "in the United Kingdom, crimes in the name of honour are rooted in cultural traditions, not religious beliefs." "It is often perceived that the Muslim faith is responsible for these practices. This article argues that this is a simplistic interpretation of the problem. It concludes that 'crimes of honour' should be treated as a violation of human rights and not as a religious or cultural practice. A number of recommendations are put forward, such as raising awareness to change attitudes, educating the judiciary and the police, employing the media and the option of introducing legislation in this sensitive area of law, and analyses the shortcomings of such proposals.

\section{B. 'CRIMES OF HonOuR' AND 'HonOur KILlingS'}

In the UK, "a number of recent high-profile cases of so-called 'honour killings' have received unprecedented media attention and have caused much debate on the subject of how to prevent and punish such crimes."

\footnotetext{
${ }^{3}$ Rupa Reddy, 'Gender, Culture and the Law: Approaches to "Honour Crimes" in the UK' (2008) Feminist Legal Studies 305-321, 305.

${ }^{4}$ ibid, 306.

${ }^{5}$ Anne Phillips, 'When Culture Means Gender: Issues of Cultural Defence in the English Courts' (2003) 66 Modern Law Review 510, 511.

${ }^{6}$ Reddy (n 3) 305.

${ }^{7} R v$ Shabir Hussain [1997] EWCA Crim 2876.

${ }^{8}$ Phillips (n 5) 525.

${ }^{9}$ United Nations General Assembly (2012), Report on the Special Rapporteur on

Violence Against Women, its Causes and Consequences [A/HRC/20/16].

${ }^{10}$ Reddy (n 3) 306.
} 
However, before such discussion emerges, we must first be clear on the definition of the ever-evolving terms; 'crimes of honour' and 'honour killings'.

\section{Definition: 'Crimes of Honour'}

The definition of 'crimes of honour' is by no means straightforward ${ }^{11}$, because it encompasses a wide range of crimes, which may be culture specific. The definition may involve

"one of a range of violent or abusive acts committed in the name of 'honour', including emotional, physical or sexual abuse and other controlling and coercive behaviours, such as forced marriage and female genital mutilation, which can end, in some extreme cases in suicide or murder." 12

The value and meaning of 'crimes of honour' is examined in some depth by Sen, who warns against western hypocrisy. ${ }^{13}$ According to Sen, the purpose of 'crimes of honour' is to "remove from a collectivity the stain of dishonour, both gendered and locally defined, through the use of emotional, social or physical coercion over a person whose actual or imputed actions have brought dishonour." Indeed, Chakravarti argues against using the term 'crimes of honour' because it "mask[s] the violence in the abuses and because the violence becomes associated with the uniqueness of Asian cultures". ${ }^{14}$ Furthermore, the imprecision of its use is more reason for caution in the use of the phrase. ${ }^{15}$

\section{What are 'Honour' Killings?}

An 'honour killing' is where a woman is killed to "either prevent or repair perceived violations of male or familial honour." "Amnesty International defines 'honour killing' as usually committed by male family members against a female relative, when they believe she has brought shame on the

\footnotetext{
${ }^{11}$ Lynn Welchman and Sara Hossain, “'Honour”, Rights and Wrongs' in Welchman and Hossain, 'Honour' (n 1).

${ }^{12}$ Hannana Siddiqui, 'There is no 'Honour' in Domestic Violence, Only Shame! Women's Struggles Against 'Honour' Crimes in the UK' in Welchman and Hossain, 'Honour' (n 1), 263.

13 ibid.

${ }^{14}$ Uma Chakravarti, 'From Fathers to Husbands of Love, Death and Marriage in North India' in Welchman and Hossain, 'Honour' (n 1), 308.

${ }^{15}$ Welchman and Hossain (n 11) 4.

${ }^{16}$ Reddy (n 3) 306.
} 
family. ${ }^{17}$ This definition clearly outlines the gender-based element of the crime, which will be explored below. In this context, "family honour is defined as an entire social behavioural code imposed on women for the purpose of enforcing their inferiority and preserving male supremacy." 18 Honour crimes punish women who have become too 'westernised"19 in the eyes of their male family members and therefore harmed the girl's ghairat (family honour). The mere perception that a woman has acted in a manner that brings 'dishonour' to the family is sufficient to trigger an attack. ${ }^{20}$

Hassan compares acts like acid throwing and stove burning which are based on revenge and greed to 'honour killings', which "are backed by a moral reasoning: if a woman acts in a way that is deemed improper, the patriarchal culture often excuses the male's attempts to reclaim his own honour and regain control over his family." 21 This shows that the "concept of men as the guardians of women's chastity is so deeply ingrained in the social fabric that it is difficult for society to condemn anyone who is seen as acting for the honour of his family." 22 Further, some identify that

"honour killings have also taken on a religious justification. Although the concept of honour killings predates Islam and is not sanctioned by Islam, these killings are commonly linked to religion because of their connection with enforcement of morality and upholding the patriarchal structure. ${ }^{, 23}$

This clearly shows that, despite the lack of direct link with Islam, the overall perception is that the crime is connected to Islamic beliefs and, as a result, it shadows the realities of the crime, which are inherent violations of human rights. However, unfortunately, these violations are hidden under the cloak of 'honour'.

${ }^{17}$ Amnesty International, 'Pakistan: No Progress on Women's Rights', September 1998. Al Index: ASA 33/13/98.

${ }^{18}$ Ursula Smartt, “"Honour Killings"” (2006) 170 The Journal Dedicated to Magisterial and Local Government Law 4, 4.

${ }^{19}$ The term 'westernised' encapsulates numerous activities, such as wearing western clothing, wearing make-up, partying in nightclubs, defying parental authority, drug or alcohol consumption, refusing to enter into an arranged marriage, being the victim of a sexual assault, seeking a divorce, committing adultery, and so on.

${ }^{20}$ Smartt (n 18).

${ }^{21}$ Yasmeen Hassan, 'Stove Burning, Acid Throwing and Honor Killings' in Kelly D Askin and Dorean M Koenig, Women and International Human Rights Law, Vol. II (Transnational Publishers Inc 2000) 603.

22 ibid 604.

${ }^{23}$ ibid. 


\section{The Statistics: 'Honour' Killings}

Honour killings remain underreported and under-documented globally. It is impossible to know the exact statistics or how widespread honour crimes are in the UK. ${ }^{24}$ One of the main reasons is that reports to the police are "rare and sporadic, with widespread family cover up," 25 including secrecy by the mother, sisters and aunts of the female victims. The few reported cases of honour killings have mainly been amongst Muslim communities in the $\mathrm{UK},{ }^{26}$ which increasingly face pressure over their religious beliefs.

In 2003, London's Metropolitan Police set up a specialist task force unit to investigate honour killings. The Metropolitan Police estimate that there are around twelve 'honour killings' per year in the UK. ${ }^{27}$ Further, "most of the reported cases in Britain involve women from Asian or Middle Eastern, and mainly, Muslim backgrounds. However, it is worthwhile to note that honour killings cut across racial, religious and cultural divides." 28 This article does not suggest that "men are not also subjected to such brutal crimes, ${ }^{29}$ however, women remain the majority of the victims and, as such, crimes of honour remain predominately a gender-based form of violence.

Honour killings represent only "the tip of the iceberg in terms of violence and abuse perpetrated against women in the name of honour." 30 The study in the social cohesion report ${ }^{31}$ shows that honour killings and domestic violence are "not isolated practices but are instead part of a self-sustaining social system built on ideas of honour and cultural, ethnic and religious superiority. ${ }^{32}$ Despite popular belief, this is not a one-time problem of first generation immigrants bringing practices from 'back home' to the UK. ${ }^{33} \mathrm{In}$ fact, honour violence is now, to all intents and purposes, "an indigenous and self-perpetuating phenomenon, which is carried out by third and fourth generation immigrants who have been raised and educated in the UK., ${ }^{34}$ This is particularly alarming, because it illustrates that there are no immediate signs of change; western lifestyle, education and societal norms

\footnotetext{
${ }^{24}$ Smartt (n 18).

${ }^{25}$ ibid.

${ }^{26}$ ibid.

${ }^{27}$ Bennetto and Judd, 2004; R.Cown, 2004; BBC News Online, 22 June 2004.

${ }^{28}$ Siddiqui (n 12).

${ }^{29}$ Welchman and Hossain (n 11).

${ }^{30}$ Centre for Social Cohesion, Crimes of the Community: Honour-based Violence in the UK ( $2^{\text {nd }}$ edn, 2010).

${ }^{31}$ ibid.

32 ibid.

33 ibid.

${ }^{34}$ ibid.
} 
have evidently had little or no influence over the perpetrators' perceptions and beliefs.

\section{Deconstructing 'Honour ${ }^{35}$}

The concept of honour is "neither a new nor a purely Islamic feature; nor is it a characteristic only of 'backward societies'., ${ }^{36}$ In fact, historic notions of 'honour' have existed in most societies, including in Britain. However, its prevalence has diminished in many western countries, although "notions of personal 'honour' and even family reputation are still common, particularly in Italian and Greek society." ${ }^{37}$ Referring to Greece, Sen notes that it is "through the holding of honour that individuals find a place in their community, and thus the concept of honour is imbued with great power" ${ }^{\prime 3}$. As such, it is evident that concepts of honour have not been entirely discarded in the west.

'Honour' essentially involves the "maintenance of strict codes of gendered behaviour" ${ }^{39}$ to control concepts of 'property' and 'shame'. It is upheld through the regulation of women's behaviour. This rests on two basic premises; firstly, historically women were (and still are, for the purposes of honour crimes) property owned by men. Secondly, women are virtuous at birth and this must be maintained throughout their lives, because a stain on a woman's chastity is a reflection of disobeying the male relatives of the family. As such, the dual notions of 'honour' and 'shame' are intrinsically linked: any stains on honour will naturally result in bringing shame to the family name.

The perception of women as the chattels of their male relatives further highlights the need to regulate their 'immoral' behaviour. Most commonly, this means policing female sexuality, which comes under strict scrutiny. Perceptions of 'honour' are linked, as Welchman and Hossain point out, not merely "to male self-worth, but more closely to the social conduct of

\footnotetext{
${ }^{35}$ The quotation marks around the term 'honour' are used to convey that fact that this article is in agreements with an increasing number of academics critical of its overall usage in distinguishing between types of gender violence.

${ }^{36}$ Purma Sen, "CCrimes of Honour": Value and Meaning' in Welchman and Hossain, 'Honour' (n 1) 61.

${ }^{37}$ Siddiqui (n 12) 264.

${ }^{38}$ Sen (n 36) 54.

${ }^{39}$ Reddy (n 3).
} 
females. ${ }^{40}$ Thereby, masculinity is largely determined in relation to female chastity, as women 'embody' the honour of males. ${ }^{41}$

As such, women are expected to remain virgins until marriage and unstained by adultery throughout their lives. As Hassan notes, a woman is tied to her family's honour, which facilitates violence against her, because to forgive an 'errant' woman would jeopardise the ability of her male relatives to hold their heads up in society. ${ }^{42}$ Policing may involve tragic acts of violence including 'honour killing' because the fact that a man has lost control over his women implies "a loss of masculinity that is more costly to

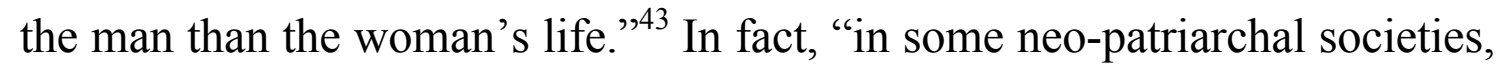
killing a deviant woman acts as a form of purification for the family, and the one who does the killing may even gain respect in the general community.",44

\section{Honour: Islamic Roots and Tensions?}

Honour killings are not just a Muslim phenomenon, even though media coverage continues to suggest that this is the case. ${ }^{45}$ As Sen notes this implication creates intrinsic issues, because by "identifying Islamic cultures as deeply imbued with backward approaches to gender relations, associating Islam intrinsically with honour killings, and highlighting Islamic cultures as therefore inherently problematic have left a tangle of anger and moral superiority." ${ }^{46}$ Such inferences are likely to cause hostility between communities and have undesirable practical consequences. ${ }^{47}$

Further, this alienates minority cultures from the west for two reasons. Firstly, it provokes anger within these communities, which feel a need to distance themselves from what they perceive as western hypocrisy, in an attempt to safeguard their norms; and secondly, this distancing results in alienation of the minority culture from the dominant western culture, which

\footnotetext{
${ }^{40}$ Welchman and Hossain (n 11).

${ }^{41}$ Welchman and Hossain (n 11) 6.

${ }^{42}$ Hassan (n 21) 590.

${ }^{43}$ ibid.

${ }^{44}$ Araji (n 2).

${ }^{45}$ Werner Menski, 'Book Reviews: Honour Crimes, Paradigms, and Violence Against Women' (2006) 20 Journal of Immigration, Asylum and Nationality Law, 144, 144-146.

${ }^{46} \operatorname{Sen}(\mathrm{n} 36) 42$.

${ }^{47}$ See Purna Sen, "'Honour Crimes” and Human Rights', Expert Meeting on Violence in the Name of Honour, Ministry of Justice, Stockholm, Sweden, 4-5 November 2003, available http://www.ebiblioteka.lt/resursai/Uzsienio\%201eidiniai/Countries/Sweden/Integration/20 03/mi2003_01.pdf.
} 
often assumes moral superiority. ${ }^{48}$ As Sen argues, these inherent tensions continue to shape and complicate the possibility of international alliances, which stand as an important alternative to conservative alliances that construe cultural values as primordial and never changing. ${ }^{49}$

\section{Consequences of Losing One's 'Honour'}

It appears that the promise of maintaining one's honour is one of the main reasons women remain in abusive homes and thus suffer continuing abuse. Indeed, the whole concept of honour acts as a "constraining factor in preventing them from leaving." ${ }^{, 50}$ This concept is two-fold: women are afraid of bringing shame on their families and destroying their family honour, ${ }^{51}$ but they equally fear the resulting "social ostracism and harassment." because of the perception that honour perpetuates in both the family home and also within the wider community. As a woman's identity is integrally linked to culture and community, women are exceptionally wary of the arrogant gaze of critical outsiders. ${ }^{53}$ Therefore, although the woman may escape abuse within the home, once she leaves, she will be subject to a different form of abuse from her community.

Furthermore, male abusers use the concept of honour to justify their violence, while honour simply serves to trap women, "by its confining nature, preventing many from leaving abusive situations and sentencing them to pariah status if they do." ${ }^{, 54}$ As such, the concept of honour acts as an excuse or justification for men, while it serves to confine women to strict behavioural codes. Therefore, honour clearly has different meanings and connotations for women and men even within the same community. In other words, the concept of 'honour' also remains entirely gendered.

\section{WOMEN'S Role IN 'HonOuR' KILLINGS}

Although mothers, sisters, aunts, female cousins, sister-in-laws or other female relatives seldom participate in the actual physical act of murder, it is undeniable that they often play a significant part. In fact, it is women who often instigate the murder or keep it secret, most commonly the mother of

\footnotetext{
${ }^{48} \operatorname{Sen}(\mathrm{n} 36) 43$.

${ }^{49}$ ibid.

${ }^{50}$ Siddiqui (n 12) 266.

${ }^{51}$ ibid.

52 ibid.

${ }^{53}$ Coomaraswamy (n 1).

${ }^{54}$ Siddiqui (n 12) 266.
} 
the victim. ${ }^{55}$ There are a number of reasons for this. For example, the alleged dishonour may undermine the family's economic and marital prospects, which is a major concern to many mothers, for two reasons. Firstly, these women are, often, predominantly financially dependent on their husbands and sons. This gives them a vested, albeit alarming, interest in maintaining the status quo and not tarnishing their husbands' and sons' family name. ${ }^{56}$ Secondly, an important part of women's role in several patriarchal communities is to produce children and heirs to carry forward the family name and to ensure that their offspring continue the cycle by entering into socially acceptable marriages. Therefore, anyone who may potentially disrupt either of these two aims is a cause of grave concern for mothers, who are prepared to take drastic steps to prevent their occurrences. Unfortunately, these drastic steps involve covering up the death of their own daughters.

The case of Rukshana $\mathrm{Naz}^{57}$ is the perfect example of women's prime involvement in the crime. Rukshana was strangled by her brother Shazad Ali for 'dishonour' with a piece of plastic flex, while her mother, Shakeela Naz, held her down and looked on. At the trial, the court learnt more about the whole family's involvement in Rukshana's killing; how her 18-year old brother, Iftikhar, had tried to stop his brother and mother's torturing, and how their mother had fended off her son Iftikhar, shouting "Be strong son!" Convicted of her murder in 1999, Rukshana's mother justified the killing, saying 'it was in her kismet' (fate). Therefore, it is evident that women play a central role in ensuring that female family members adhere to gender norms. ${ }^{58}$

\section{1. 'Honour Crimes': Domestic Violence?}

Domestic violence is commonly described as a form of emotional, psychological and/or physical abuse suffered by women at the hands of their husbands or male partners. A common factor that links domestic violence to honour crimes is that in both, there appears to be a "common cultural expectation of silent endurance from the woman." 59 However, this is where the similarities stop. In western societies, there is increasing community awareness of domestic violence and its consequences, largely thanks to

\footnotetext{
${ }^{55}$ Necla Mora, 'Violence as a Communicative Action: Customary and Honour Killings' (2009) 6:2 International Journal of Human Sciences 503.

${ }^{56}$ Araji (n 2).

${ }^{57} R v$ Shakeela Naz [2000] ECWA Crim 24.

${ }^{58}$ Sen (n 36) 48.

${ }^{59}$ Smartt (n 18) 5.
} 
public awareness programmes. Victims are encouraged by the police to come forward and report their abuse. However, in the case of honour crimes, "such incidences remain largely under-reported and under-investigated," due to the 'shame' that such exposure would bring.

\section{2. 'Honour Crimes': Gender Violence?}

Gender-based violence is a form of "discrimination that seriously inhibits women's ability to enjoy rights and freedoms on a basis of equality with men." ${ }^{\prime 61}$ The definition of discrimination includes gender-based violence, that is, violence that is directed against a woman because she is a woman or that affects women disproportionately. It includes acts that inflict physical, mental or sexual harm or suffering, threats of such acts, coercion and other deprivations of liberty.

The concept of 'honour' impacts mainly, but by no means exclusively, the female sex. Traditional attitudes place a heavier burden on women than on men, in order for the former to conform to specific ideals of 'honour'. This is because, as discussed further in section B above, the very concepts of 'honour' and 'shame' revolve around female sexuality and the regulation of female chastity. ${ }^{62}$ For these reasons, "it would seem appropriate to classify such crimes as a form of gender-based violence against women." ${ }^{\text {"3 }}$ Thus, as has already been argued above, 'honour' applies unequally to men and women.

Nevertheless, "while 'honour' is mainly used to control women's autonomy, some men may also come under pressure to conform to prescribed forms of behaviour." ${ }^{64}$ However, the pressure exerted on men is to a much lesser extent than their female counterparts. The standards include fulfilling their role as a "dutiful son in order to preserve the reputation of the family name." ${ }^{, 65}$ Yet, while, for instance, an extreme derivation from the standard behavioural code such as homosexuality, "incurs severe stigma and

\footnotetext{
${ }^{60}$ ibid.

${ }^{61}$ Committee on the Elimination of All Forms of Discrimination Against Women (CEDAW) (1992), General Recommendation No. 19: Violence Against Women [U.N. Doc. A/47/38].

${ }^{62}$ Committee on the Elimination of All Forms of Discrimination Against Women (1992) [U.N. Doc. A/47/38] (n 63).

${ }^{63}$ Reddy (n 3) 307.

${ }^{64}$ Siddiqui (n 12) 264.

${ }^{65}$ ibid.
} 
condemnation, in general homosexual men face no or less severe consequences in comparison to women." 66

The issue of male victims creates difficulty in labeling the violence as gender-related. In fact, in the UK, some politicians have attempted to argue that the crimes are "gender-neutral, since some men have also been the victims of 'honour killings' in the past." ${ }^{67}$ However, as Siddiqui argues, "it is easier for men to escape such situations, whereas women, by contrast, face far greater pressure to reconcile themselves to abusive situations." ${ }^{\text {"68 }}$ The male victims of honour crimes are more often than not, the 'westernised' or forbidden boyfriends/partners of the disgraced women. This may, for example, involve pre-marital sex or even adulterous relationships during marriage. Therefore, it is possible to argue that the men who suffer the same fatal consequences as women in the name of 'honour', do so because they have contributed to the shame brought on the woman's family. The two are intrinsically linked. Thus, without attempting to simply dismiss or deny the victimisation of males in certain cases, it is still possible to argue that their victimisation revolves around attempts to control women, and that it is a form of gender-based violence. ${ }^{69}$

\section{D. 'HonOur CRIMES ' AND UK LAW}

The law surrounding honour crimes is a complex legal issue in the UK. ${ }^{70}$ While some Muslim countries condone honour killings, in the UK such crimes fall within the criminal codes governing homicide under the Homicide Act 1957 or serious offences against the person, under the Offences Against the Person Act 1861. Therefore, the criminal law in the UK requires punishment of the perpetrator. However, the offenders often seek a defence in their cultural tradition. In particular, defendants seek to justify their acts as customary norms and seek mitigation on the ground that the murder was committed as a consequence of protecting the family honour. This creates a problem for Western legislators and law enforcement agencies, who are not trained on how to handle the cultural differences between different communities and how this may impact criminal

\footnotetext{
${ }^{66}$ Siddiqui (n 12) 264.

${ }^{67}$ Reddy (n 3) $307-308$.

${ }^{68}$ Siddiqui (n 12) 308.

${ }^{69}$ Reddy (n 3) 308.

${ }^{70}$ Smartt (n 18) 6.
} 
sanctions. ${ }^{71}$ Smartt argues, "whilst honour crimes are increasingly occurring in Western European territories, they are often compounded by state ignorance and indifference by law enforcement agencies or courts." ${ }^{, 72}$ For this reason "under no circumstances should a judge permit a form of cultural or religious defence [...] as a legal defence of provocation.,"73

In the UK, provocation is a partial defence to homicide pursuant to the Homicide Act 1957. Both a subjective and an objective test must be satisfied in order to establish the defence of provocation. The subjective element determines whether the defendant suffered from a sudden and temporary loss of self-control, whereas the objective element determines whether a reasonable man would have acted in the same way as the defendant. ${ }^{74}$

\section{Historic Origins of the Provocation Defence}

In the 2003 Consultation Paper on 'Partial Defences to Homicide', the Law Commission of England and Wales found that the defence of provocation is "historically rooted in male notions of honour." 75 However, although men in Britain continue to use cultural defences, they no longer refer to 'honour' as a motivating factor. ${ }^{76}$ Instead, in Western societies, "men's excuses for murder often rest on 'nagging and shagging' defences, which caused the man to 'snap' and kill out of anger." 77 Thus, the association of honour with murder or domestic violence is now mainly applicable to ethnic minority communities in the $\mathrm{UK}^{78}$

The cultural defence raises two major issues. Firstly, growing concern is raised among feminists who argue that the culture defence "reinforces patriarchal power." acts on the basis of cultural norms and therefore escape the full force of the law. Philips argues that, in this context, culture operates to sustain male power. ${ }^{80}$ Indeed, it "weighs the interests of defendants above those of victims, and is particularly damaging to women." 81

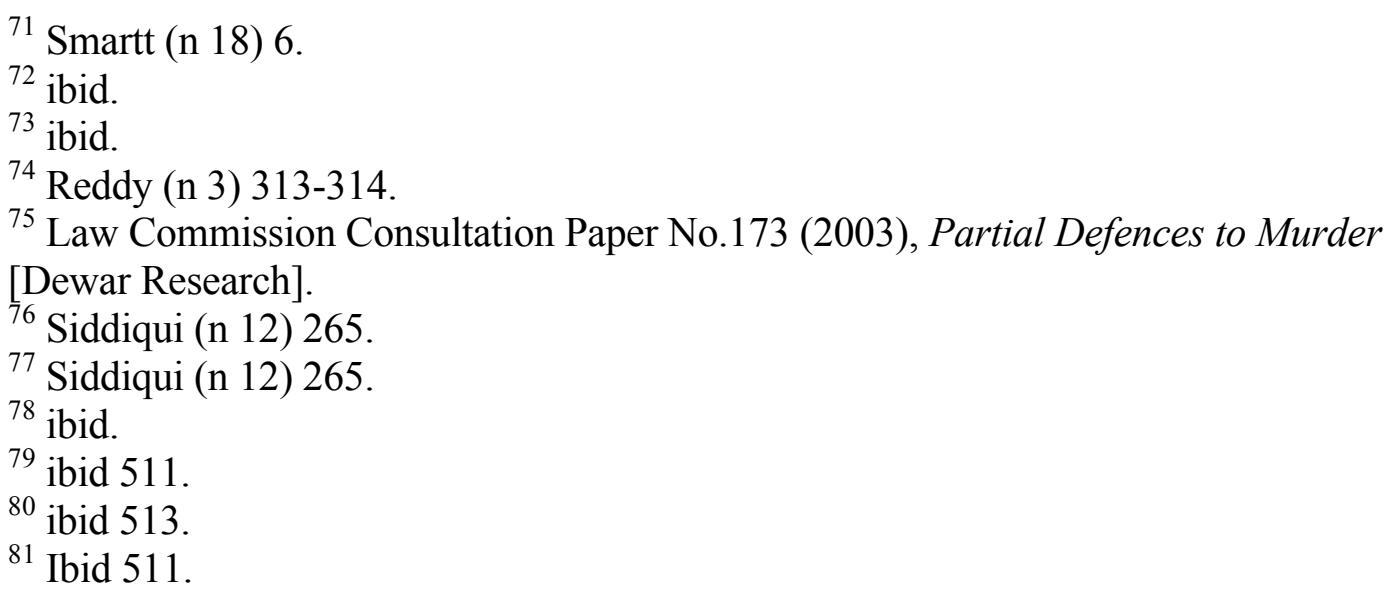


Secondly, allowing 'honour' as a plea in mitigation "runs contrary to the due diligence element of modern thinking on human rights, $" 82$ which places an obligation on the state to protect all its citizens equally. Honig rightly argues that "women's rights are human rights, and they must be protected from violence as well as from idiosyncratic harm. ${ }^{, 83}$ It seems that the notion of 'honour' often overshadows the basic, systemic elements of such crimes, which are clear violations of human rights. It also "indicates a threat that runs through cultures and contexts regarding the way social and cultural norms of gender seep from society to criminal justice systems." ${ }^{\$ 4}$

\section{2. 'Honour Crimes' in the UK Courts}

This section examines the approach of the English courts to the culture defence in cases of 'honour killings'. The question is whether cultural belief is a characteristic that can be taken into account in assessing provocation. ${ }^{85}$ This issue can be contextualised by the Rukhsana $\mathrm{Naz}^{86}$ case, discussed above, where cultural considerations were introduced but not accepted as justifying the plea of provocation. This was also the case in $R v$ Faqir Mohammed, ${ }^{87}$ where the judge stated, "a man may not rely on his own violent disposition, by way of excuse," ${ }^{, 88}$ and the defendant was found guilty of murder and sentenced to life imprisonment.

However, a worrying exception to this pattern is illustrated in the case of $R v$ Shabir Hussain ${ }^{89}$ where the defendant was convicted of murdering his sister-in-law by driving into her and then reversing the car over her body. In his judgment, the judge acknowledged that her illicit affair "would be deeply offensive to someone with [his] background and [his] religious beliefs," and therefore, the defendant was sentenced "on the basis that something blew up in [his] head that caused a complete and sudden loss of selfcontrol." ${ }^{\text {191 }}$ Based on this comment, it seems that the defendant's cultural beliefs affected the gravity of his sentence. The concern is that acceptance of

\footnotetext{
${ }^{82} \operatorname{Sen}(\mathrm{n} 36) 49$.

${ }^{83}$ Bonnie Honig, 'My Culture Made Me Do It' in Susan Moller Okin, Is Multiculturalism Bad for Women? (Princeton University Press 1999), 36.

${ }^{84}$ Sen (n 36) 49.

${ }^{85}$ Reddy (n 3) 314.

${ }^{86} R v$ Shakeela Naz [2000] ECWA Crim 24.

${ }^{87}$ [2005] EWCA Crim 1880.

${ }^{88}$ Manchester Crown Court, 18 Feb 2002 (transcript: Cater Walsh and Co).

${ }^{89}$ [1997] EWCA Crim 2876.

${ }^{90} R$ v Shabir Hussain, Newscastle Crown Court, 28 July 1998 (transcript: J. L. Harpham Ltd).

91 ibid.
} 
the defence could potentially affect not only the question of penalty but, similarly also the question of guilt. ${ }^{92}$ Nevertheless, while this is a troubling exception, the English courts have not been particularly receptive to provocation pleas based on intensely held religious beliefs or cultural understandings of honour and shame. ${ }^{93}$

However, the case law highlights a number of problems. Firstly, courts allude to stereotypes of cultures and portray them as static. ${ }^{94}$ Judicial discourse on an "alleged 'clash of cultures' implies the cultural superiority of the western communities, as well as fuelling the stereotyping of ethnic minority cultures." ${ }^{95}$ Secondly, the judgments uphold the idea of honour as primarily cultural, rather than gender-based. Thus, a more culturally-focused approach prevails at the expense of sensitivity to broader issues of gender violence. ${ }^{96}$ This separates honour-related violence from other forms of violence against women, which "in turn hinders attempts to locate honourrelated violence within the wider arena of gender violence, and to enable rights-based approaches to the protection of women, such as 'mature multiculturalism,", 97

\section{Culture Defence: Academic Opinion}

There are varying degrees of opposition to the cultural defence among both academics and activists. Abu-Odeh points out that, while it is impossible to completely do away with the notion of male honour in the law of Muslim societies, "the provocation exception exhibits a continuum of acceptance of honour crimes as a necessary means to an end. ${ }^{, 98}$ In contrast, Philips adopts a more stringent outlook and argues that the "cultural defence is a highly dubious development and ought to be stopped in its tracks." 99 Indeed, the danger is that defendants' use the excuse of honour as a blanket cover for a multitude of sins. ${ }^{100}$

\footnotetext{
${ }_{92}^{92}$ Phillips (n 5) 527.

93 ibid.

${ }^{94}$ Reddy (n 3) 316.

95 ibid.

${ }^{96}$ ibid 313.

97 ibid 316.

${ }^{98}$ Lama Abu-Odeh, 'Feminism, Nationalism and the Law: The Case of Arab Women' (1993) (unpublished Ph.D. dissertation, Harvard Law School, at 50-56 cited in Yasmeen Hassan, 'Stove Burning, Acid Throwing and Honor Killings' in Kelly D Askin and Dorean M Koenig, Women and International Human Rights Law, Vol. II (Transnational Publishers Inc 2000) 601.

${ }^{99}$ Phillips (n 5) 516.

${ }^{100}$ Welchman and Hossain (n 11) 8.
} 
While it is widely accepted that the courts need to demonstrate multicultural sensitivity ${ }^{101}$, it is argued that allowing a cultural defence threatens to elevate cultural membership above other considerations. ${ }^{102}$ Indeed, the claim that ' $m y$ culture made me do it' implies a kind of privilege, which places cultural reasoning above other factors. ${ }^{103}$ Philips argues that ignorance of the law is not normally accepted as a legitimate defence. "Why then should the courts accept ignorance that derives from cultural difference?"104 Members of minority cultures have used "culture' as an excuse for cruelty and violations of human rights for too long. ${ }^{105}$ If we allow the culture defence then we are effectively opening the floodgates to the possibility of offering one's culture as an excuse for any kind of aberrant behaviour. ${ }^{106}$ Indeed, we must prevent the "societal practice of connecting a 'crime' with a mitigating value of 'honour" ${ }^{107}$ It is hoped that the use of these cultural arguments will remain exceptional, rather than indicating a recent trend of accepting such practices as excuses for violent crimes.

Feminists such as Philips argue that the defence of culture should be excluded from the courtroom, ${ }^{108}$ and this article is in full agreement with this position. Indeed, 'legal provisions which grant 'honour' as a mitigating defence should be ended." "I09 If not, the danger is that defendants could clearly employ culture in opportunistic ways. ${ }^{110}$ For example, "one might well exaggerate the centrality of certain practices to one's 'culture' in order to establish a defence." 111 The consequence is that the courts may start to accept such crimes as 'normal' within a different cultural context. ${ }^{112}$

\section{E. Multiculturalism}

The arguments put forward by this article so far have focused on a genderbased approach to honour crimes. There is however a line of argument which allocates such crimes more specifically to certain cultures. This is particularly relevant within the multicultural context of the UK, where

\footnotetext{
${ }^{101}$ Phillips, (n 5) 511.

102 ibid, 513.

${ }^{103}$ Honig (n 83) 36.

${ }^{104}$ Phillips (n 5) 513.

${ }^{105}$ Honig (n 83) 36.

${ }^{106}$ Phillips (n 5) 514.

${ }^{107}$ Welchman and Hossain (n 11) 9.

108 ibid, 511.

${ }^{109}$ Sen (n 36) 58.

${ }^{110}$ Phillips (n 5) 517.

${ }_{111}$ Phillips (n 5) 517.

112 ibid.
} 
reporting of such crimes has, to date, only taken place in relation to ethnic minority communities. ${ }^{113}$ Multiculturalism was initially introduced in the UK with the aim of combating racism. The concept aims to "promote an integrated and tolerant society, where the diversity of cultures and races are valued equally". ${ }^{114}$ Nonetheless, as Siddiqui observes, at its best, multiculturalism aims "to promote racial tolerance," $" 115$ but at its worst, it "fails to address power inequalities such as sexual oppression within communities". ${ }^{116}$ The intended aims of multiculturalism have thus faced intense debate. The final part of this article aims to reconcile the feminist perspective with a multicultural outlook.

\section{Multiculturalism: the Debate}

Feminist theorists such as Okin are critical of multiculturalism because it pays more attention to the differences between groups, leaving power imbalances within groups unquestioned. ${ }^{117}$ Siddiqui agrees that while multiculturalism "aims to promote racial harmony between communities, [it] fails to address problems within communities, such as oppressive practices against women." 118 This is particularly relevant to the case of "honour crimes', where the power imbalances between men and women within the family household are largely left unregulated.

Some cultures can be oppressive because of the values or social roles they instill. ${ }^{119}$ In light of this, Okin argues that some cultures may in fact be worthy of extinction. ${ }^{120}$ This statement is remarkable in its honesty, ${ }^{121}$ but embarrassing in its lack of tolerance. As Honig pervasively argues, there are brutal men (and women) everywhere; "is it their religious identity, which makes them brutal, or is it their brutality?"122 Thus, "extinguishing cultures is not the answer." ${ }^{123}$ However, the host culture is often judgmental and

\footnotetext{
${ }^{113}$ Reddy (n 3$) 309$.

114 ibid.

${ }^{115}$ Siddiqui (n 12) 278.

116 ibid.

${ }^{117}$ Susan Moller Okin, Is Multiculturalism Bad for Women? (Princeton University Press 1999) 12.

${ }^{118}$ Siddiqui (n 12) 271.

${ }^{119}$ Robert Post, 'Between Norms and Choices', in Susan Moller Okin, Is Multiculturalism Bad for Women? (Princeton University Press 1999) 67.

${ }^{120}$ Okin (n 117) 40.

${ }^{121}$ Azizah Y. Al-Hibri, 'Is Western Patriarchal Feminism Good for Third World/Minority Women?' in Susan Moller Okin, Is Multiculturalism Bad for Women? (Princeton

University Press 1999) 41.

${ }^{122}$ Honig (n 83) 36.

123 ibid 40.
} 
unforgiving of cultural differences within ethnic minority communities. There are two potential consequences to this; firstly, minority cultures become marginalised and secluded from wider society, which further widens the gap between different communities; or they feel pressure to conform and, therefore, become acculturated, thus losing their own distinct cultural roots. Distinguishing between enabling and oppressive cultural norms is a fundamental challenge of liberal multiculturalism and one which has yet to be successfully confronted. ${ }^{124}$

\section{Multiculturalism v Feminism}

There is a question to be posed as to whether feminism is well served by multiculturalism. ${ }^{125}$ Okin claims that there is a distinct, deep tension between feminism and multiculturalism. ${ }^{126}$ While multiculturalism "celebrates the diversity of cultures, including the diversity of gender roles, feminism is dedicated precisely to constraining the available repertory of such roles." ${ }^{, 127}$ "The feminist challenge to liberal multiculturalism thus forces feminism to sharpen its own normative claims."

The concept of multiculturalism has highlighted an important contradiction with the issue of women's rights, which feminists argue has suffered a detrimental impact. For example, community leaders who have "little or no interest in social justice" ${ }^{129}$ often represent the interests of minority communities. In this process, social divisions and the interests of women are largely ignored. Acting as "mediators between the state and minority communities, community leaders cultivate a relationship with the state," 130 which "rarely challenges the status quo for the sake of maintaining good community or race relations." ${ }^{131}$ As a result, the state has often turned a blind eye to oppressive practices, in "an effort to appear 'culturally sensitive' and 'tolerant of diversity'." 132 Therefore, once again, the more radical voices of women are compromised by the more conservative forces within the community. ${ }^{133}$ Nonetheless, in the words of Home Office Minister, Mike

\footnotetext{
${ }^{124}$ Post (n 119) 68.

${ }^{125}$ Honig (n 83) 37.

${ }^{126}$ Okin (n 117).

${ }^{127}$ Post (n 119) 65.

${ }^{128}$ ibid, 66.

${ }^{129}$ Siddiqui (n 12) 271.

130 ibid.

131 ibid.

132 ibid.

133 ibid, 271.
} 
O’Brien, "multi-cultural sensitivity is no excuse for moral blindness."

\section{3. 'Mature Multiculturalism'}

'Mature multiculturalism' is a concept advocated by leading feminists, such as Siddiqui, who highlight the human rights breaches of such crimes, over and above any links to the cultural heritage of the victims or their perpetrators. Siddiqui argues 'that 'mature multiculturalism' should be about taking forward the human rights agenda and bridging the gap between race and gender." 135

It is argued that multiculturalism is often used as an excuse for the violation of women's rights by inhumane practices in the community and family, despite being contrary to international human rights law. ${ }^{136}$ Thereby, 'mature multiculturalism' urges us to "resist the all-too-familiar and dangerous temptation to mark foreignness itself as fundamentally threatening to women." 137 Reddy argues that a 'mature multiculturalism' approach would perhaps better ensure that the positive aspects of understanding cultural issues are utilised by the courts, at the same time as not allowing them to replace the right to be free from gender violence, including honour-related violence. ${ }^{138}$

\section{F. TIME FOR ACTION?}

Although some government officials have expressed concern over 'honour killings,' they have not made any public announcements or taken specific initiatives to address the issue. ${ }^{139}$ Indeed, it is not enough to condemn the crimes without developing specific strategies to prevent their occurrence. ${ }^{140}$ However, as media coverage of honour killings has increasingly intensified, law enforcement agencies and the courts are forced to address the issues of norms and values within the home. ${ }^{141}$

1. Raising Awareness to Change Attitudes - This involves adopting preventive measures and creating long-term goals of changing prevailing

134 ibid.

${ }^{135}$ Siddiqui (n 12) 279.

${ }^{136}$ Coomaraswamy (n 1).

${ }^{137}$ Honig (n 83) 40.

${ }^{138}$ Reddy (n 3) 317.

${ }^{139}$ Siddiqui (n 12) 269.

${ }^{140}$ Abdullahi Ahmed An-Na'im, 'The Role of 'Community Disclosure' in Combating

'Crimes of Honour' Preliminary Assessment and Prospects' in Welchman and Hossain,

'Honour' (n 1), 64.

${ }^{141}$ Committee on the Elimination of All Forms of Discrimination Against Women (1992)

[U.N. Doc. A/47/38] (n 71). 
attitudes about the roles and status of men and women, ${ }^{142}$ by providing education at all levels. ${ }^{143}$ The two main aims of education should be: a) to challenge and remove any prejudices that hinder women's equality, ${ }^{144}$ and ultimately change society's views on women's position in society, and b) to empower women by making them aware of their existing rights and informing them that this form of abuse is common, rather than an isolated phenomenon. ${ }^{145}$ Special educational programmes would be provided specifically for "women and men from communities where such crimes occur." 146

2. Educating the Judiciary - These professional institutions need to be educated about the background to Islamic culture and influences, because judges have the power to "help shift social attitudes by legally condemning abusive behaviour." "147 Therefore, by providing gendersensitive training ${ }^{148}$ to the judiciary, this will enable them to deal with complaints impartially. ${ }^{149}$ This can be effectively accomplished by completing a series of seminars and conferences. It has also been suggested that gender and cultural issues should be made part of a curriculum for incoming judges. However, this can be part of a wider, long-term agenda.

3. Educating the Police - It is essential that the police be trained to respond positively to a woman's appeals for help, because having law enforcement on her side can be critical to her survival. ${ }^{150}$ Therefore, the police should be trained not to view women's problems as private and trivial domestic squabbles, but as a matter to be taken seriously. Siddiqui argues; "unless the police understand and deal with all the extra obstacles these women experience, including the impact of racism, their

\footnotetext{
${ }^{142}$ Committee on the Elimination of All Forms of Discrimination Against Women (1992) [U.N. Doc. A/47/38] (n 62).

${ }^{143}$ Hassan (n 21) 604.

${ }^{144}$ Committee on the Elimination of All Forms of Discrimination Against Women (1992) [U.N. Doc. A/47/38] (n 62).

${ }^{145}$ Hassan (n 21) 604.

${ }^{146}$ Council of Europe (2003), 'So-called 'Honour Crimes' [Parliamentary Assembly, Resolution 1327, $4^{\text {th }}$ April 2003].

${ }^{147}$ Hassan (n 21) 607.

${ }^{148}$ Committee on the Elimination of All Forms of Discrimination Against Women (1992)

[U.N. Doc. A/47/38] (n 62).

${ }^{149}$ Council of Europe (2003) (n 146).

${ }^{150}$ Hassan (n 21) 607.
} 
response will be inadequate or even racist if based on stereotypical views of the community". 151

4. Legislation - There is currently a lack of legislation tailored to combat the problem of honour-based violence and its specificities. However, it is clearly not sufficient to merely enact legislation addressing honour crimes. This is firstly because, as discussed throughout this article, women are unlikely to bring a claim against their abuser given the lack of options to leave abusive homes ${ }^{152}$ and secondly, due to community efforts to hide violence in the first place. Therefore, legislation addressing this issue has to be combined with other preventative measures. In particular, in order for legislation to be effective, there needs to be a change in societal attitudes. As such, we must challenge ignorance by raising issues in the "wider political arena through campaigning and policy interventions." 153

5. Media - The media play a crucial role in reinforcing social perceptions. ${ }^{154}$ However, media stories are often driven towards sensationalism, rather than raising awareness. Hassan argues; "widely circulated newspapers must acknowledge their impact on social attitudes and strive for more socially conscious approach to reporting." ${ }^{155}$ On the one hand, there are often complaints that not enough cases are brought to the attention of the public at large and that certain events are left unknown. On the other, when news items of this sort become an everyday article, which people become accustomed to reading, emotional distance between the reader and the victims appears to build up. Therefore, the media should aim to strike a sensitive balance between under-reporting and over-reporting cases. ${ }^{156}$ Of course, this raises the issue of enforcement in relation to obligations on the media and relates to the role played by the media in modern society. This is a combination of education and social understanding and acceptance. Indeed, the media could be the driving force to help "launch national awareness-raising campaigns, in schools, universities and religious

\footnotetext{
${ }^{151}$ Siddiqui (n 12) 278.

152 Hassan (n 21) 604.

${ }^{153}$ Siddiqui (n 12).

${ }^{154}$ Hassan (n 21) 605.

${ }^{155}$ Hassan (n 21) 60.

${ }^{156}$ Committee on the Elimination of All Forms of Discrimination Against Women (1992)

[U.N. Doc. A/47/38] (n 71).
} 
institutions in order to discourage and prevent 'honour crimes'."157 The impact of the media does not end with newspapers. Television documentaries, the internet and numerous other resources available through modern technology, could provide a useful aid to inform and educate great numbers of people regarding violence conducted in the name of 'honour'.

\section{G. CONCLUSION}

In a "world dominated by rapid social change, many [...] men may view the home as their last bastion of male authority." minority communities in the UK thus face a particularly tough struggle, torn between two worlds. On the one hand, they are exposed to western culture through television, music, clothes and travel, so they may want to conform to majority culture and assert their individual rights within society. However, on the other hand, they have been raised to respect their cultural traditions and many do so with a true sense of pride. The problem of honour-based crimes thus arises where the extremity of these traditions clashes with modern western lifestyles. ${ }^{159}$ This is because, even though women are exposed to modern lifestyles in the UK, "notions of honour continue to be associated with the women of the family." 160 This places a heavy burden on their shoulders, balancing their ancestral heritage against their own personal desires to express freedom of mind and conform to western society. The result is deeply alarming to men, who desperately cling onto and fervently support culturally ingrained norms and traditions relating to their role in the household and the shame associated with their loss of control over the women that live with them or bear their name. There is thus a real fear of change, which ultimately leads to increased feelings of humiliation, irrationality and ultimately violence, thus ultimately affecting, primarily, women. ${ }^{161}$

In its traditional sense, 'honour' is the cement between families and communities but, as this essay has tried to argue, it is also capable of upholding patriarchal values and, thus, of allowing men to escape the full force of the law under the guise of cultural defences. By way of conclusion, it is worth observing that "notions of honour should have more positive

\footnotetext{
${ }^{157}$ Council of Europe (2003) (n 146).

${ }^{158}$ Social Cohesion Report (n 30).

${ }^{159}$ Social Cohesion Report (n 30).

${ }^{160}$ Hassan (n 21) 598

161 ibid.
} 
connotations, such as respecting a sense of 'personal honour', dignity and integrity." ${ }^{162}$ As such, violence in the name of honour is a 'dishonourable' act, which requires punishment of the perpetrator, and not the victim. ${ }^{163}$ It is not women who should be condemned by the community for bringing 'shame' and 'dishonour' on the family, but rather the men who perpetrate the abuse. ${ }^{164}$

The law in this area has not always served women well. In some instances, law enforcement agencies have turned a blind eye and courts have allowed defendants to use the excuse of 'honour' to justify acts of violence by providing a cultural cloak of legitimacy. This article has argued that the culture defence under a plea of provocation should be completely aborted. This is because the human rights breaches of such crimes override any links to the cultural heritage of the victims or their perpetrators. As an increasing number of honour-related violence cases are "subjected to judicial scrutiny, it is hoped that a fairer balance [will be] achieved between both gender and cultural factors." 165 The solution is for the courts to be sensitive to the circumstances of each individual case, ${ }^{166}$ and yet to remain stringent in their unwillingness to accept provocation excuses to murder.

While many attempts have been made by feminist activists and human rights groups to improve the situation for women suffering in silence, which have in turn "produced greater awareness and pressure for change, there is still a long way to go to ensure the state effectively deals with honour killings in the future." ${ }^{.67}$ As such, this article has aimed to set out some of the enormous and multiple challenges that activists in this field continue to face. However, the struggle is a difficult one, requiring a more united approach, ${ }^{168}$ with strong support from the state and politicians. The state has often avoided confronting the issue at large by labeling such practices as 'cultural'. It is important to acknowledge that there is a "distinction between the need to protect cultures and turning a blind eye to unacceptable customs that amount to torture and/or a breach of human rights."

We need to work together to establish a strong network, build alliances and give victims a voice. This can be done by reconciling the

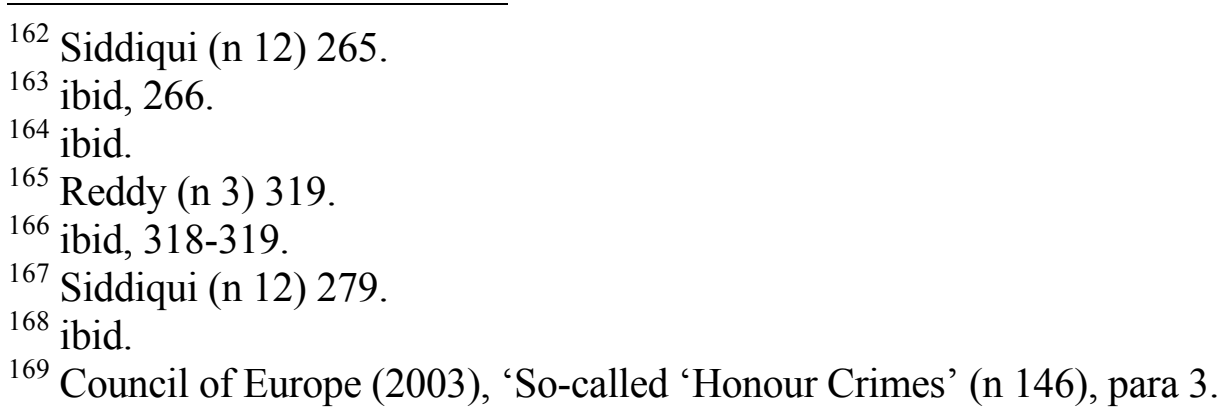


feminist approach with mature multiculturalism. Siddiqui argues that "one struggle should not be waged at the expense of another, and our common goal must be to fight for the rights of all rather than the rights of a few." ${ }^{170}$ It is time for the West to "join hands in collective action to address crimes of honour" ${ }^{\text {"171 }}$ and to build a shared framework for common understanding with minority communities.

${ }^{170}$ Siddiqui (n 12) 274.

${ }^{171} \operatorname{Sen}(\mathrm{n} 36)$. 